\title{
Hydration change of aqueous lanthanide ions and tetrad effects in lanthanide(III)-carbonate complexation
}

\author{
IWAO KAWABE \\ Department of Earth and Planetary Sciences, Graduate School of Science, Nagoya University, \\ Chikusa, Nagoya 464-8602, Japan
}

(Received February 23, 1998; Accepted April 16, 1999)

\begin{abstract}
Lanthanide(III)-carbonate complexes, $\mathrm{LnCO}_{3}{ }^{+}(\mathrm{aq})$ and $\mathrm{Ln}\left(\mathrm{CO}_{3}\right)_{2}{ }^{-}(\mathrm{aq})$, are the principal $\mathrm{Ln}$ (III) species in seawater. Their logarithmic stability constants, $\log \beta_{1}\left(\operatorname{Ln}\left(\mathrm{CO}_{3}\right)^{+}\right)$and $\log \beta_{2}\left(\operatorname{Ln}\left(\mathrm{CO}_{3}\right)_{2}^{-}\right)$defined by total carbonate ion concentration, are known to show "irregular" variations across the series. The irregularities are explained by the hydration change of light $\mathrm{Ln}^{3+}(\mathrm{aq})$ and the refined spin-pairing energy theory (RSPET). The hydration change of $\mathrm{Ln}^{3+}(\mathrm{aq})$ affects the stability constants, because they are given by the reactions of $\mathrm{Ln}^{3+}(\mathrm{aq})$ with $\mathrm{CO}_{3}{ }^{2-}(\mathrm{aq})$ and $2 \mathrm{CO}_{3}{ }^{2-}(\mathrm{aq})$, respectively. However, it does not affect their ratio of $\left[\mathrm{B}_{2}\left(\mathrm{Ln}\left(\mathrm{CO}_{3}\right)_{2}{ }^{-}\right) / \mathrm{B}_{1}\left(\mathrm{LnCO}_{3}{ }^{+}\right)\right]$which is the stepwise stability constant of $\mathrm{Ln}\left(\mathrm{CO}_{3}\right)_{2}{ }^{-}(\mathrm{aq})$ for the reaction: $\mathrm{LnCO}_{3}{ }^{+}(\mathrm{aq})+\mathrm{CO}_{3}{ }^{2-}(\mathrm{aq})=\mathrm{Ln}\left(\mathrm{CO}_{3}\right)_{2}^{-}(\mathrm{aq})$. Only when corrected for the hydration change of $\mathrm{Ln}^{3+}(\mathrm{aq})$, the $\log \beta_{1}\left(\operatorname{Ln}\left(\mathrm{CO}_{3}\right)^{+}\right)$values exhibit a regular convex tetrad effect across the series. Similarly corrected $\log \beta_{2}\left(\operatorname{Ln}\left(\mathrm{CO}_{3}\right)_{2}^{-}\right)$values also show a convex tetrad effect with a small break at Pr. The $\log \left[\beta_{2}\right.$ $\left.\left(\mathrm{Ln}\left(\mathrm{CO}_{3}\right)_{2}^{-}\right) / \mathrm{B}_{1}\left(\mathrm{LnCO}_{3}{ }^{+}\right)\right]$values are fairly constant, but display a small octad effect with convexity and the small break at Pr. The $\mathrm{LnCO}_{3}{ }^{+}(\mathrm{aq})$ series appears to be an isomorphous complex series, but the $\mathrm{Ln}\left(\mathrm{CO}_{3}\right)_{2}{ }^{-}$ (aq) series involves a structural change between the three lightest Ln members and the others. The RSPET

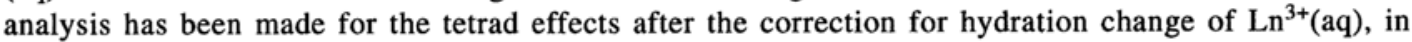
which the small break at $\operatorname{Pr}$ in $\log \beta_{2}\left(\operatorname{Ln}\left(\mathrm{CO}_{3}\right)_{2}{ }^{-}\right)$has also been corrected successfully. It was revealed that Racah $\mathrm{E}^{1}$ and $\mathrm{E}^{3}$ parameters decrease in the order that $\mathrm{Ln}^{3+}(\mathrm{aq}$, octahydrate $) \gg \mathrm{LnCO}_{3}{ }^{+}(\mathrm{aq})>\mathrm{Ln}\left(\mathrm{CO}_{3}\right)_{2}{ }^{-}$ (aq). This corresponds to the nephelauxetic effect known in spectroscopic studies of $\mathrm{Ln}(\mathrm{III})$ complexes.
\end{abstract}

\section{INTRODUCTION}

The lanthanide(III)-carbonate complexation is important for understanding the REE characteristics of seawater and marine deposits, since $\mathrm{LnCO}_{3}{ }^{+}(\mathrm{aq})$ and $\mathrm{Ln}\left(\mathrm{CO}_{3}\right)_{2}{ }^{-}(\mathrm{aq})$ are known as the most dominant $\mathrm{Ln}(\mathrm{III})$ species in seawater (Turner et al., 1981; Byrne et al., 1988). Byrne and coworkers reported the stability constants for $\mathrm{LnCO}_{3}{ }^{+}(\mathrm{aq})$ and $\mathrm{Ln}\left(\mathrm{CO}_{3}\right)_{2}{ }^{-}(\mathrm{aq})$ defined by total carbonate ion concentration in $0.7 \mathrm{M} \mathrm{NaClO}_{4}$ at $25^{\circ} \mathrm{C}$ and 1 atm pressure (Cantrell and Byrne, 1987; Lee and Byrne, 1993; Liu and Byrne, 1995). They have determined the stability constants by means of tributyl phosphate solvent extraction using REE radioisotopes (Lundqvist, 1982). Because of the radioisotopes necessary for the tech- nique, such determinations have been made for a limited number of $\mathrm{Ln}(\mathrm{III})$-carbonate complexes $(\mathrm{Ln}=\mathrm{Ce}, \mathrm{Eu}, \mathrm{Gd}, \mathrm{Tb}, \mathrm{Yb})$ and $\mathrm{Y}(\mathrm{III})$-carbonate complexes. The stability constants for the other Ln members have been estimated by empirical correlations among stability constants for various aqueous Ln(III) complexes (Lee and Byrne, 1992, 1993). The logarithmic stability constants for $\mathrm{LnCO}_{3}{ }^{+}(\mathrm{aq})$ and $\mathrm{Ln}\left(\mathrm{CO}_{3}\right)_{2}{ }^{-}(\mathrm{aq})$ do not show smooth variations across the Ln series (Fig. 1 and Table 1). Lee and Byrne (1993) noted that the stability constants for Gd are smaller relative to those for $\mathrm{Eu}$ and $\mathrm{Tb}$. They pointed out that similar " $\mathrm{Gd}$ anomalies" are recognized in various stability constants for Ln(III)-organic complexes. No specific explanation has been given to the "Gd anomalies" yet. 
Table 1. Stability constants of $\beta_{1}\left(\mathrm{LnCO}_{3}{ }^{+}\right)$and $\left.\beta_{2}\left(\mathrm{LnCO}_{3}\right)_{2}{ }^{-}\right)$for lanthanide(III)-carbonate complexation and those for yttrium(III) analogues*

\begin{tabular}{|c|c|c|c|}
\hline & $\log B_{1}\left(\mathrm{LnCO}_{3}{ }^{+}\right)$ & $\log B_{2}\left(\operatorname{Ln}\left(\mathrm{CO}_{3}\right)_{2}^{-}\right)$ & References** \\
\hline $\mathrm{La}$ & 4.97 & 8.76 & \\
\hline $\mathrm{Ce}$ & 5.27 & 9.37 & (a) \\
\hline $\operatorname{Pr}$ & 5.41 & 9.66 & \\
\hline $\mathrm{Nd}$ & 5.52 & 9.84 & \\
\hline $\mathrm{Pm}$ & 5.63 & 9.98 & \\
\hline $\mathrm{Sm}$ & 5.73 & 10.12 & \\
\hline $\mathrm{Eu}$ & 5.81 & 10.14 & (a) \\
\hline Gd & 5.67 & 10.14 & (a), (b) \\
\hline $\mathrm{Tb}$ & 5.79 & 10.26 & (a) \\
\hline Dy & 5.85 & 10.41 & \\
\hline Ho & 5.88 & 10.46 & \\
\hline $\mathrm{Er}$ & 5.96 & 10.64 & \\
\hline $\operatorname{Tm}$ & 6.04 & 10.78 & \\
\hline $\mathrm{Yb}$ & 6.14 & 10.95 & (a) \\
\hline $\mathrm{Lu}$ & 6.14 & 11.03 & \\
\hline Y & 5.71 & 10.34 & (b) \\
\hline
\end{tabular}

*All the stability constants are at $0.7 \mathrm{M}\left(\mathrm{NaClO}_{4}\right)$ ionic strength, $25^{\circ} \mathrm{C}$ and 1 atm pressure.

**(a): Lee and Byrne (1993), (b): Liu and Byrne (1995). The experimental values are indicated by $(a)$ and/or $(b)$ in the column of references. The Gd results are averages of the two references. The values with no reference are estimated by the empirical deviations relative to Gd results (Lee and Byrne, $1992,1993)$. They are given by $\log \left[\beta_{i}(L n)\right]-\log \left[\beta_{i}(G d)\right]=$ $\log \left[\beta_{i}^{(0)}(L n)\right]-\log \left[\beta_{i}^{(0)}(G d)\right]$, where $\beta_{i}(L n)$ for $i=1$ and 2 corresponds to $\beta_{1}\left(\mathrm{LnCO}_{3}{ }^{+}\right)$and $\beta_{2}\left(\mathrm{Ln}\left(\mathrm{CO}_{3}\right)_{2}{ }^{-}\right)$, respectively. The superscript $(0)$ means the stability constant at zero ionicstrength and $25^{\circ} \mathrm{C}$. The values of $\log \left[\beta_{i}^{(0)}(\mathrm{Ln})\right]$ are found in Table 3 of Lee and Byrne (1993).

The aim of this study is to examine the "Gd anomalies" and "irregular" series variations of stability constants for $\mathrm{LnCO}_{3}{ }^{+}(\mathrm{aq})$ and $\mathrm{Ln}\left(\mathrm{CO}_{3}\right)_{2}{ }^{-}(\mathrm{aq})$ from the viewpoints of the hydration change of light $\mathrm{Ln}^{3+}$ (aq) (Habenschuss and Spedding, 1980) and the refined spin-pairing energy theory (RSPET) for lanthanide tetrad effects (Jørgensen, 1979; Kawabe, 1992). Recently Kawabe (1999) reported the quantitative examination of the series variations of thermochemical parameters for solution of isomorphous crystalline $\mathrm{Ln}$ (III) hydrates series from the same viewpoints. The $\mathrm{Ln}^{3+}(\mathrm{aq})$ series is involved not only in the solution of $\mathrm{Ln}$ (III) hydrate series but also in Ln(III) complex formation in aqueous solution like $\mathrm{LnCO}_{3}{ }^{+}(\mathrm{aq})$ and $\mathrm{Ln}\left(\mathrm{CO}_{3}\right)_{2}^{-}(\mathrm{aq})$.

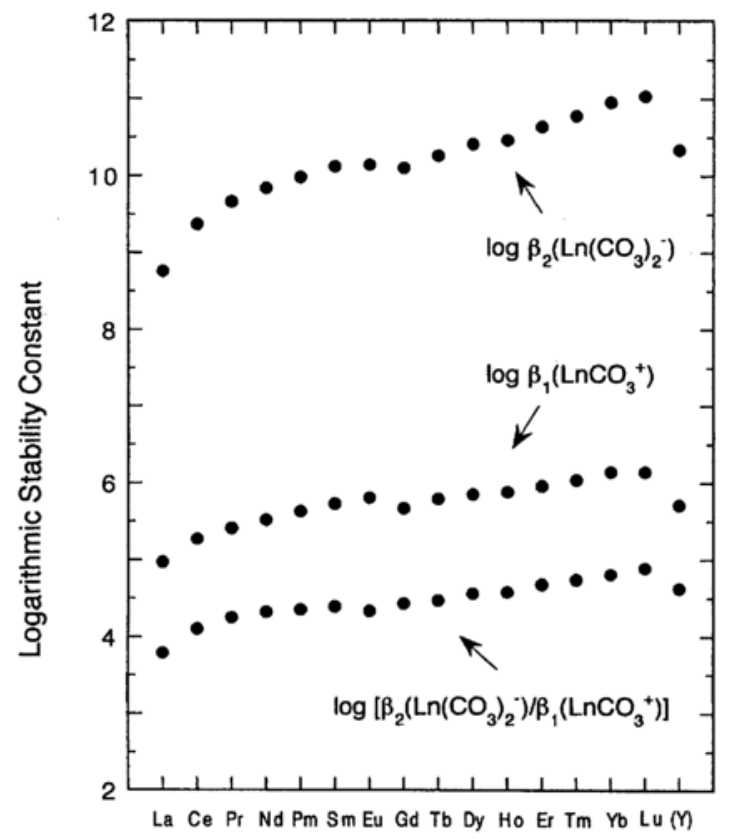

Fig. 1. Stability constants for $\beta_{1}\left(\mathrm{LnCO}_{3}{ }^{+}\right)$and $\beta_{2}\left(\mathrm{Ln}\left(\mathrm{CO}_{3}\right)_{2}^{-}\right)$in $0.7 \mathrm{M} \mathrm{NaClO}_{4}$ at $25^{\circ} \mathrm{C}$ and $1 \mathrm{~atm}$. Their ratios are also shown. Individual data including those for Y-carbonate complexes and their sources are listed in Table 1.

\section{BACKGROUNDS OF Ln(III) COMPLEX FORMATIONS}

Hydration change of $\mathrm{Ln}^{3+}(a q)$, lanthanide tetrad effect and solution of isomorphous crystalline Ln(III) hydrates

The structure of first coordination sphere of aqueous lanthanide(III) ion changes across the light Ln series (Habenschuss and Spedding, 1980). According to their $\mathrm{X}$-ray diffraction studies of aqueous $\mathrm{LnCl}_{3}$ solutions, aqueous $\mathrm{Ln}^{3+}$ ions from $\mathrm{La}^{3+}$ through $\mathrm{Nd}^{3+}$ are nonahydrates, those between $\mathrm{Nd}^{3+}$ and $\mathrm{Tb}^{3+}$ are transitional between nona- and octahydtates, and those from $\mathrm{Tb}^{3+}$ to $\mathrm{Lu}^{3+}$ are octahydrates. Their conclusion has been supported basically by subsequent X-ray and neutron diffraction studies and by EXAFS (Extended $\mathrm{X}$-ray Absorption Fine Structure) measurements as reviewed by Ohtaki and Radnai (1993). A majority of various data from Raman, fluorescence, visible spectroscopies, thermodynamic and trans- 
port properties of $\mathrm{Ln}^{3+}$ ions in aqueous solutions are in favor of the change of hydration number of light $\mathrm{Ln}^{3+}(\mathrm{aq})$ series (Rizkalla and Choppin, 1991 and references therein).

The structural change in light $\mathrm{Ln}^{3+}(\mathrm{aq})$ series can also be recognized as an irregular series variation of the heat of solution for lanthanide ethyl sulfate nonahydrates $\left(\mathrm{LnES}_{3} \cdot 9 \mathrm{H}_{2} \mathrm{O}\right.$ with $\mathrm{ES}=$ $\mathrm{C}_{2} \mathrm{H}_{5} \mathrm{SO}_{4}^{-}$). This was first pointed out by Staveley et al. (1968) and then by Mioduski and Siekierski (1976). In addition, the latter authors emphasized that the relative variations of $\Delta \mathrm{G}$ 's for crystalization and co-crystallization of $\mathrm{LnES}_{3} \cdot 9 \mathrm{H}_{2} \mathrm{O}$ indicate the "double-double" effect in heavy Ln series. The term "double-double" effect is the same as the tetrad effect by Peppard et al. (1969). It is well-known that $\mathrm{LnES}_{3} \cdot 9 \mathrm{H}_{2} \mathrm{O}$ comprise a fully isomorphous $\mathrm{Ln}(\mathrm{III})$ hydrate series: Their first coordination polyhedra of $\mathrm{Ln}^{3+}$ ions are written as $\left[\mathrm{Ln}\left(\mathrm{H}_{2} \mathrm{O}\right)_{9}\right]^{3+}$ which have tricapped trigonal prismatic structures across the entire $\mathrm{Ln}$ series (Albertsson and Elding, 1977; Gerkin and Reppart, 1984). The unique property of $\mathrm{LnES}_{3} \cdot 9 \mathrm{H}_{2} \mathrm{O}$ enables us to discuss the sturctural change of light $\mathrm{Ln}^{3+}(\mathrm{aq})$ series in terms of the heat of solution for the crystalline hydrate series.

In order to examine more quantitaively the points raised by Staveley et al. (1968) and Mioduski and Siekierski (1976), the present author (Kawabe, 1999) evaluated thermochemical parameters for solution $\left(\Delta \mathrm{G}_{\mathrm{s}}{ }^{\circ}, \Delta \mathrm{H}_{\mathrm{s}}{ }^{\circ}\right.$ and $\left.\Delta \mathrm{S}_{\mathrm{s}}{ }^{\circ}\right)$ of $\mathrm{LnES}_{3} \cdot 9 \mathrm{H}_{2} \mathrm{O}$ at $25^{\circ} \mathrm{C}$ and $1 \mathrm{~atm}$, and then compared them with $\Delta \mathrm{G}_{\mathrm{s}}{ }^{\circ}, \Delta \mathrm{H}_{\mathrm{s}}{ }^{\circ}$ and $\Delta \mathrm{S}_{\mathrm{s}}{ }^{\circ}$ for $\mathrm{LnCl}_{3} \cdot 6 \mathrm{H}_{2} \mathrm{O}$ (Spedding et al., 1977). Their series variations have been examined by the refined spinpairing energy theory (RSPET) (Jørgensen, 1979; Kawabe, 1992). As a result, Kawabe (1999) concluded that the series variations of $\Delta \mathrm{G}_{\mathrm{s}}{ }^{\circ}, \Delta \mathrm{H}_{\mathrm{s}}{ }^{\circ}$ and $\Delta \mathrm{S}_{\mathrm{s}}{ }^{\circ}$ for the isomorphous $\mathrm{Ln}(\mathrm{III})$ hydrates can be separated into the three characteristic variations:

(a) the effect of hydration change in light $\mathrm{Ln}^{3+}(\mathrm{aq})$ series,

(b) a tetrad effect variation originated from the differences in Racah $\left(E^{1}\right.$ and $\left.E^{3}\right)$ parameters between octahydrate $\mathrm{Ln}^{3+}(\mathrm{aq})$ and each $\mathrm{Ln}(\mathrm{III})$ hydrate series, and (c) a smooth residual variation.

The conclusions have much relevance with $\mathrm{Ln}$ (III) complex formations, because $\mathrm{Ln}$ (III) complex formations are similar to solution reactions of crystalline Ln(III) hydrates as below.

\section{Ln(III) complex formation compared with solution of crystalline $\operatorname{Ln}($ III) hydrates}

The solution of each $\mathrm{LnES}_{3} \cdot 9 \mathrm{H}_{2} \mathrm{O}$ in water is written by

$\mathrm{LnES}_{3} \cdot 9 \mathrm{H}_{2} \mathrm{O}(\mathrm{c})=\mathrm{Ln}^{3+}(\mathrm{aq})+3 \mathrm{ES}^{-}(\mathrm{aq})+9 \mathrm{H}_{2} \mathrm{O}(\mathrm{l})$.

Since $\mathrm{Ln}^{3+}(\mathrm{aq})$ with $\mathrm{Ln}=\mathrm{Tb}-\mathrm{Lu}$ are all octahydrate ions, the reaction (1) is identical with the following one,

$$
\begin{aligned}
\operatorname{LnES}_{3} \cdot 9 \mathrm{H}_{2} \mathrm{O}(\mathrm{c})= & \mathrm{Ln}^{3+}(\mathrm{aq}, \text { octahydrate }) \\
& +3 \mathrm{ES}^{-}(\mathrm{aq})+9 \mathrm{H}_{2} \mathrm{O}(\mathrm{l}) .
\end{aligned}
$$

For $\mathrm{Ln}^{3+}(\mathrm{aq})$ with $\mathrm{Ln}=\mathrm{La}-\mathrm{Gd}$, however, the reactions of (1) and (2) are not identical, because $\mathrm{Ln}^{3+}(\mathrm{aq})$ are real species but $\mathrm{Ln}^{3+}$ (aq, octahydrate) are hypothetical ones for light $\mathrm{Ln}$. The difference between Eqs.(1) and (2) gives us a single equation for light $\mathrm{Ln}^{3+}(\mathrm{aq})$,

$$
\operatorname{Ln}^{3+}(\mathrm{aq}, \text { octahydrate })=\operatorname{Ln}^{3+}(\mathrm{aq}) .
$$

Hence the values of $\Delta \mathrm{G}_{\mathrm{r}}{ }^{\circ}(3)=\Delta \mathrm{G}_{\mathrm{s}}{ }^{\circ}(1)-$ $\Delta \mathrm{G}_{\mathrm{s}}{ }^{\circ}(2) \equiv \Delta \mathrm{G}_{\mathrm{h}}{ }^{*}$ for light $\mathrm{Ln}$ series describe the stabilization of real $\mathrm{Ln}^{3+}(\mathrm{aq})$ relative to hypothetical $\mathrm{Ln}^{3+}\left(\mathrm{aq}\right.$, octahydrate). Similarly, $\Delta \mathrm{H}_{\mathrm{r}}^{\circ}(3)=$ $\Delta \mathrm{H}_{\mathrm{s}}{ }^{\circ}(1)-\Delta \mathrm{H}_{\mathrm{s}}{ }^{\circ}(2) \equiv \Delta \mathrm{H}_{\mathrm{h}}{ }^{*}$ and $\Delta \mathrm{S}_{\mathrm{r}}{ }^{\circ}(3)=$ $\Delta \mathrm{S}_{\mathrm{s}}{ }^{\circ}(1)-\Delta \mathrm{S}_{\mathrm{s}}{ }^{\circ}(2) \equiv \Delta \mathrm{S}_{\mathrm{h}}{ }^{*}$ are defined. The thermochemical parameters for (1) are known experimentally as $\Delta \mathrm{G}_{\mathrm{s}}{ }^{\circ}, \Delta \mathrm{H}_{\mathrm{s}}{ }^{\circ}$ and $\Delta \mathrm{S}_{\mathrm{s}}{ }^{\circ}$ of $\mathrm{LnES}_{3} \cdot 9 \mathrm{H}_{2} \mathrm{O}$ for the entire Ln series. The parameters for (2) in the light $\mathrm{Ln}$ series can be estimated, if $\Delta \mathrm{G}_{\mathrm{s}}^{\circ}, \Delta \mathrm{H}_{\mathrm{s}}{ }^{\circ}$ and $\Delta \mathrm{S}_{\mathrm{s}}{ }^{\circ}$ of $\mathrm{LnES}_{3} \cdot 9 \mathrm{H}_{2} \mathrm{O}$ in the heavy $\mathrm{Ln}$ series are extrapolated properly into the light $\mathrm{Ln}$ series (Kawabe, 1999). Individual values for $\Delta \mathrm{G}_{\mathrm{h}}{ }^{*}, \Delta \mathrm{H}_{\mathrm{h}}{ }^{*}$ and $\Delta \mathrm{S}_{\mathrm{h}}{ }^{*}$ for $\mathrm{Ln}^{3+}(\mathrm{aq})$ with $\mathrm{Ln}=$ La-Gd except Pm have been estimated in Kawabe (1999). 
The parameters of $\Delta \mathrm{G}_{\mathrm{h}}{ }^{*}$ are very important to consider series variations of complex formation constants of $\mathrm{Ln}^{3+}$ in aqueous solutions. When an anionic ligand of $\mathrm{X}$ with charge of $(-z)$ reacts with $\mathrm{Ln}^{3+}(\mathrm{aq})$ to form a complex of $\left.[\mathrm{LnX}]_{\mathrm{m}}\right]^{3-\mathrm{mz}}(\mathrm{aq})$ in aqueous solution,

$$
\operatorname{Ln}^{3+}(\mathrm{aq})+\mathrm{mX}^{-\mathrm{z}}(\mathrm{aq})=\left[\operatorname{LnX}_{\mathrm{m}}\right]^{3-\mathrm{mz}}(\mathrm{aq})
$$

the complex formation constant of $\mathrm{K}$ and $\Delta \mathrm{G}_{\mathrm{r}}{ }^{\circ}$ for the reaction (4) are related to each other as usual:

$$
R T \ln K=2.303 R T \log K=-\Delta G_{r}^{\circ}(4) .
$$

The value of $2.303 R T \log \mathrm{K}$ is equal to the $\Delta \mathrm{G}_{\mathrm{r}}{ }^{\circ}$ value for its reverse reaction, i.e., the dissociation reaction of the complex;

$$
\left[\operatorname{LnX}_{\mathrm{m}}\right]^{3-\mathrm{mz}}(\mathrm{aq})=\operatorname{Ln}^{3+}(\mathrm{aq})+\mathrm{mX}^{-\mathrm{z}}(\mathrm{aq}) \text {, }
$$

and then

$$
R T \ln K=2.303 R T \log K=\Delta G_{r}^{\circ}(5) .
$$

The series variation of $\log \mathrm{K}$ for the $\mathrm{Ln}$ (III) complex formation corresponds to that of $\Delta \mathrm{G}_{\mathrm{r}}{ }^{\circ}$ for the dissociation reaction of the same complex. $\mathrm{Ln}^{3+}(\mathrm{aq})$ is always on the right-hand side of the dissociation reaction (5) just like in the solution reactions of crystalline $\mathrm{Ln}(\mathrm{III})$ hydrates in water as in (1) and (2). Hence, as in the case of $\Delta \mathrm{G}_{\mathrm{s}}{ }^{\circ}$ values for $\mathrm{LnES}_{3} \cdot 9 \mathrm{H}_{2} \mathrm{O}$ and $\mathrm{LnCl}_{3} \cdot 6 \mathrm{H}_{2} \mathrm{O}$ (Kawabe, 1999), the series variation of $\log \mathrm{K}$ for $\mathrm{Ln}(\mathrm{III})$ complex formation involves the following characteristic variations:

(I) the effect of hydration change in light $\mathrm{Ln}^{3+}(\mathrm{aq})$ series,

(ii) a tetrad effect variation when Racah $\left(E^{1}\right.$ and $E^{3}$ ) parameters are different between octahydrate $\mathrm{Ln}^{3+}(\mathrm{aq})$ and $\left[\mathrm{LnX}_{\mathrm{m}}\right]^{3-\mathrm{mz}}(\mathrm{aq})$,

(iii) an irregular change like a break or step when a structural change is occurring across $\left[\mathrm{LnX}_{\mathrm{m}}\right]^{3-\mathrm{mz}}(\mathrm{aq})$ series, and

(iv) a smooth residual variation.

When octahydrate $\mathrm{Ln}^{3+}(\mathrm{aq})$ on the right-hand side of (5) have greater Racah $\left(E^{1}\right.$ and $E^{3}$ ) parameters relative to $\left.[\mathrm{LnX}]_{m}\right]^{3-m z}(a q)$ on the left, the series variation of $\log \mathrm{K}$ indicates a convex tetrad effect variation. On the contrary, when octahydrate $\mathrm{Ln}^{3+}(\mathrm{aq})$ has smaller Racah $\left(\mathrm{E}^{1}\right.$ and $\left.\mathrm{E}^{3}\right)$ parameters relative to $\left[\mathrm{LnX}_{\mathrm{m}}\right]^{3-\mathrm{mz}}(\mathrm{aq})$, the series variation of $\log \mathrm{K}$ displays a concave tetrad effect. This relationship is the same as that in $\Delta \mathrm{G}_{\mathrm{s}}{ }^{\circ}$ for solution of $\mathrm{LnES}_{3} \cdot 9 \mathrm{H}_{2} \mathrm{O}$ and $\mathrm{LnCl}_{3} \cdot 6 \mathrm{H}_{2} \mathrm{O}$ (Kawabe, $1999)$. When the series variation of $\log \mathrm{K}$ displays a break or step which cannot be explained by (i) or (ii), a structural change in $\left[\mathrm{LnX}_{\mathrm{m}}\right]^{3-\mathrm{mz}}(\mathrm{aq})$ series is conceivable as the reason for (iii). From the viewpoints, we will examine the $\mathrm{Ln}$ (III)-carbonate complex formation constants.

\section{RESULTS AND DISCUSSION}

Series variations of stability constants for Ln(III)carbonate complexes

The values of $\log \beta_{1}\left(\mathrm{LnCO}_{3}{ }^{+}\right)$and $\log \beta_{2}\left(\mathrm{Ln}\left(\mathrm{CO}_{3}\right)_{2}^{-}\right)$summarized in Table 1 are adopted in this study. The experimental stability constants for $\mathrm{Ln}$ (III)-carbonate complexes ( $\mathrm{Ln}=$ $\mathrm{Ce}, \mathrm{Eu}, \mathrm{Gd}, \mathrm{Tb}, \mathrm{Yb}$ ) in $0.7 \mathrm{M} \mathrm{NaClO}_{4}$ at $25^{\circ} \mathrm{C}$ have been reported by Lee and Byrne (1993) and Liu and Byrne (1995). The stability constants for the other Ln members have been estimated by linear free energy relationships (Lee and Byrne, 1992, 1993). Their stability constants for $\mathrm{LnCO}_{3}{ }^{+}(\mathrm{aq})$ and $\mathrm{Ln}\left(\mathrm{CO}_{3}\right)_{2}{ }^{-}(\mathrm{aq})$ are defined by using the total carbonate ion concentration;

$$
B_{1}\left(\mathrm{LnCO}_{3}{ }^{+}\right)=\left[\mathrm{LnCO}_{3}{ }^{+}, \mathrm{aq}\right] /\left\{\left[\mathrm{Ln}^{3+}, \mathrm{aq}\right] \cdot\left[\mathrm{CO}_{3}{ }^{2-}\right]_{\mathrm{T}}\right\},
$$

$$
\begin{aligned}
& B_{2}\left(\operatorname{Ln}\left(\mathrm{CO}_{3}\right)_{2}{ }^{-}\right) \\
& \quad=\left[\operatorname{Ln}\left(\mathrm{CO}_{3}\right)_{2}{ }^{-}, \mathrm{aq}\right] /\left\{\left[\mathrm{Ln}^{3+}, \mathrm{aq}\right] \cdot\left[\mathrm{CO}_{3}{ }^{2-}\right]_{\mathrm{T}}{ }^{2}\right\},
\end{aligned}
$$

where

$$
\left[\mathrm{CO}_{3}{ }^{2-}\right]_{\mathrm{T}}=\left[\mathrm{CO}_{3}{ }^{2-}\right]+\left[\mathrm{NaCO}_{3}{ }^{-}\right]
$$

$\mathrm{K}$ for (4) and B's in (6) and (7) are defined by using activities and molar concentration values of relevant species, respectively. Therefore, $\log \mathrm{K}$ and $\log \beta$ are not exactly the same. The relationship 
that $\log \mathrm{K}=\log \beta+$ constant, however, holds for $\mathrm{LnCO}_{3}{ }^{+}$and $\mathrm{Ln}\left(\mathrm{CO}_{3}\right)_{2}^{-}$(Lee and Byrne, 1993). Hence their series variations are approximately the same.

In Fig. 2 we illustrated how the effect of hydration change in light $\mathrm{Ln}^{3+}(\mathrm{aq})$ is eliminated by using $\Delta \mathrm{G}_{\mathrm{h}}{ }^{*}$ values by Kawabe (1999). Only by the correction of $\Delta \mathrm{G}_{\mathrm{h}} * /(2.303 \mathrm{RT})$, the values of $\log \beta_{1}\left(\mathrm{LnCO}_{3}{ }^{+}\right)$exhibit a typical convex tetrad effect. A similar convex tetrad effect can also be recognized in the series variation of $\log B_{2}\left(\operatorname{Ln}\left(\mathrm{CO}_{3}\right)_{2}^{-}\right)$after the correction, but its tetrad effect variarion is not so symmetric as that of corrected $\log \beta_{1}\left(\mathrm{LnCO}_{3}{ }^{+}\right)$. The corrected values of $\log \beta_{2}\left(\mathrm{Ln}\left(\mathrm{CO}_{3}\right)_{2}^{-}\right)$with $\mathrm{Ln}=\mathrm{La}$ and $\mathrm{Ce}$ are still

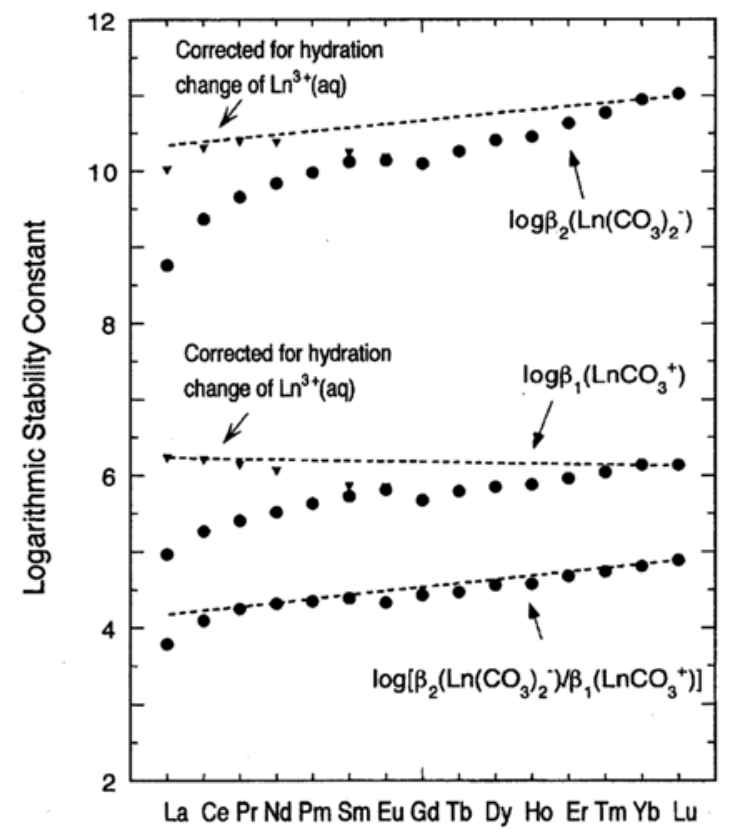

Fig. 2. The series variations of $\log \beta_{1}\left(\mathrm{LnCO}_{3}{ }^{+}\right)$, $\log \beta_{2}\left(\operatorname{Ln}\left(\mathrm{CO}_{3}\right)_{2}^{-}\right)$and $\log \left\{\beta_{2}\left(\operatorname{Ln}\left(\mathrm{CO}_{3}\right)_{2}{ }^{-}\right) / \beta_{1}\left(\operatorname{LnCO}_{3}{ }^{+}\right)\right\}$. The inverted triangles for $\log \beta_{1}\left(\mathrm{LnCO}_{3}{ }^{+}\right)$and $\log \beta_{2}\left(\mathrm{Ln}\left(\mathrm{CO}_{3}\right)_{2}^{-}\right)$are the values corrected for hydration change in light $\mathrm{Ln}^{3+}(\mathrm{aq})$ by using $\Delta G_{h}{ }^{*} /(2.303 R T)$ in Kawabe (1999). The corrected values mean the logarithmic stability constants for $\mathrm{LnCO}_{3}{ }^{+}(\mathrm{aq})$ and $\mathrm{Ln}\left(\mathrm{CO}_{3}\right)_{2}^{-}(\mathrm{aq})$ by the reactions of $\mathrm{Ln}^{3+}(a q$, octahydrate $)$ with $\mathrm{CO}_{3}{ }^{2-}(\mathrm{aq})$ and $2 \mathrm{CO}_{3}{ }^{2-}(\mathrm{aq})$, respectively. In order to emphasize their characteristic series variations, dashed lines connecting data points for heavy $\mathrm{Ln}(\mathrm{Yb}$ and $\mathrm{Lu}$ ) and light $\mathrm{Ln}$ (Pr and/or Ce and La) are shown. slightly too small to be a regular tetrad effect.

In Fig. 2 we also showed the series variation of $\log \left[\mathrm{B}_{2}\left(\mathrm{Ln}\left(\mathrm{CO}_{3}\right)_{2}{ }^{-}\right) / \mathrm{B}_{1}\left(\mathrm{LnCO}_{3}{ }^{+}\right)\right]$. The ratio of $\left[\beta_{2}\left(\operatorname{Ln}\left(\mathrm{CO}_{3}\right)_{2}{ }^{-}\right) / \beta_{1}\left(\mathrm{LnCO}_{3}{ }^{+}\right)\right]$is related to the stepwise stability constant of $\mathrm{Ln}\left(\mathrm{CO}_{3}\right)_{2}{ }^{-}(\mathrm{aq})$ for the successive complex formation:

$$
\mathrm{LnCO}_{3}{ }^{+}(\mathrm{aq})+\mathrm{CO}_{3}{ }^{2-}(\mathrm{aq})=\mathrm{Ln}\left(\mathrm{CO}_{3}\right)_{2}^{-}(\mathrm{aq}) \cdot(9)
$$

Hence the stepwise stability constant should be free from the hydration change in light $\mathrm{Ln}^{3+}(\mathrm{aq})$. Indeed, the logarithmic ratios do not show a steep inclination in light $\mathrm{Ln}$ series unlike those of $\log \beta_{1}\left(\mathrm{LnCO}_{3}{ }^{+}\right)$and $\log \beta_{2}\left(\operatorname{Ln}\left(\mathrm{CO}_{3}\right)_{2}{ }^{-}\right)$. The effect of hydration change in light $\mathrm{Ln}^{3+}(\mathrm{aq})$ is exactly canceled out in $\log \left[\mathrm{B}_{2}\left(\mathrm{Ln}\left(\mathrm{CO}_{3}\right)_{2}{ }^{-}\right) / \beta_{1}\left(\mathrm{LnCO}_{3}{ }^{+}\right)\right]$. However, an aberration from the linear trend starting at $\mathrm{Pr}$ is recognized in the series variation of $\log \left[\mathrm{B}_{2}\left(\mathrm{Ln}\left(\mathrm{CO}_{3}\right)_{2}{ }^{-}\right) / \mathrm{B}_{1}\left(\mathrm{LnCO}_{3}{ }^{+}\right)\right]$. This is the minor irregularity observed at the same position of the series variation of $\log \beta_{2}\left(\mathrm{Ln}\left(\mathrm{CO}_{3}\right)_{2}^{-}\right)$after the correction by $\Delta \mathrm{G}_{\mathrm{h}} * /(2.303 \mathrm{RT})$. The aberration or break occurring at between $\mathrm{Pr}$ and La suggests a structural change in $\mathrm{Ln}\left(\mathrm{CO}_{3}\right)_{2}{ }^{-}(\mathrm{aq})$ series at the position. The $\log \left[\mathrm{B}_{2}\left(\mathrm{Ln}\left(\mathrm{CO}_{3}\right)_{2}{ }^{-}\right) / \mathrm{B}_{1}\left(\mathrm{LnCO}_{3}{ }^{+}\right)\right]$values for $\mathrm{Eu}, \mathrm{Gd}$ and $\mathrm{Tb}$ are systematically smaller than the linear trend given by $\mathrm{Pr}, \mathrm{Yb}$ and $\mathrm{Lu}$ values by about 0.1 (Fig. 2), suggesting a faintly convex octad effect. The errors for $\log B_{1}\left(\mathrm{LnCO}_{3}{ }^{+}\right)$and $\log \beta_{2}\left(\operatorname{Ln}\left(\mathrm{CO}_{3}\right)_{2}^{-}\right)$are about \pm 0.05 for the experimentally determined values (Lee and Byrne, 1993). Although the small systematic variation of $\log \left[\beta_{2}\left(\operatorname{Ln}\left(\mathrm{CO}_{3}\right)_{2}{ }^{-}\right) / \beta_{1}\left(\mathrm{LnCO}_{3}{ }^{+}\right)\right]$is close to the experimental errors, it is an important feature as well as the break at between Pr and La.

Examination by refined spin-pairing energy theory

If we can make the corrections for the structural changes in light $\mathrm{Ln}^{3+}(\mathrm{aq})$ and in $\mathrm{Ln}\left(\mathrm{CO}_{3}\right)_{2}{ }^{-}$ (aq) series, the two sets of values for $\log \beta_{2}\left(\operatorname{Ln}\left(\mathrm{CO}_{3}\right)_{2}{ }^{-}\right)$and $\log \beta_{1}\left(\mathrm{LnCO}_{3}{ }^{+}\right)$can be fitted to the equation of refined spin-pairing energy theory (Kawabe, 1992, 1999):

$$
\begin{aligned}
\log B^{\prime}(\mathrm{q}) \cong \mathrm{A} & +(\mathrm{a}+\mathrm{bq}) \mathrm{qZ}^{*}+(9 / 13) n(\mathrm{~S}) \mathrm{C}_{1} \mathrm{Z}^{*} \\
& +m(\mathrm{~L}) \mathrm{C}_{3} \mathrm{Z}^{*},
\end{aligned}
$$


where the primed $B$ means that effects due to all the structural changes in relevant $\mathrm{Ln}$ (III) series are corrected. Since the electronic configuration of $\mathrm{Ln}^{3+}$ is written as $[\mathrm{Xe}](4 \mathrm{f})^{\mathrm{q}}, \mathrm{Ln}^{3+}$ is designated by the number of $4 \mathrm{f}$ electrons of $\mathrm{q}$. The effective nuclear charge $\left(\mathrm{Z}^{*}\right)$ for 4 f electrons of $\mathrm{Ln}^{3+}$ is related to the number of $4 \mathrm{f}$ electrons of $\mathrm{q}$ itself; $\mathrm{Z}^{*}=\mathrm{q}+25$. The constant coefficients, $n(\mathrm{~S})$ and $m(\mathrm{~L})$, are given by the total spin quantum number of $\mathrm{S}$ and the total orbital one of $\mathrm{L}$ for the groundlevel electronic configuration of $[\mathrm{Xe}](4 \mathrm{f})^{q}$. The constants of $\mathrm{A}, \mathrm{a}, \mathrm{b}, \mathrm{C}_{1}$, and $\mathrm{C}_{3}$ are determined in the least-squares fitting. The first and second terms in (10) express a smooth variation. The third and fourth terms correspond to the tetrad effect variation in $\Delta \mathrm{G}_{\mathrm{r}}^{\circ} /(2.303 \mathrm{RT})$ for the dissociation reaction of (5) after the corrections for structural changes in the relevant $\mathrm{Ln}(\mathrm{III})$ complex series.

The data of $\log \beta_{1}\left(\mathrm{LnCO}_{3}{ }^{+}\right)$in Table 1 were corrected for the hydration change effect of light $\mathrm{Ln}^{3+}(\mathrm{aq})$ by using $\Delta \mathrm{G}_{\mathrm{h}}{ }^{*} /(2.303 \mathrm{RT})$ in Kawabe (1999), and then the $\log \beta^{\prime}{ }_{1}\left(\mathrm{LnCO}_{3}{ }^{+}\right)$values were fitted to Eq. (10) by the least-squares method. For the data of $\log B_{2}\left(\mathrm{Ln}\left(\mathrm{CO}_{3}\right)_{2}^{-}\right)$in Table 1, the corrections for the hydration change effect and for the structural change effect in light $\mathrm{Ln}\left(\mathrm{CO}_{3}\right)_{2}{ }^{-}$(aq) were made, although the latter corrections were based at first on simple guess values from Fig. 2, and then the $\log \beta^{\prime}{ }_{2}\left(\operatorname{Ln}\left(\mathrm{CO}_{3}\right)_{2}^{-}\right)$values were fitted to Eq. (10) by the least-squares method. The leastsquares fitting was repeated with changing the correction values for the structural change effect in light $\left.\mathrm{Ln}\left(\mathrm{CO}_{3}\right)_{2}{ }^{-} \mathrm{aq}\right)$ by trial and error until a satisfactory fitting result was obtained. As a result, we have estimated that $\log \beta_{2}\left(\operatorname{Ln}\left(\mathrm{CO}_{3}\right)_{2}{ }^{-}\right)$for $\mathrm{Ln}=\mathrm{La}, \mathrm{Ce}$ and $\mathrm{Pr}$ are lowered, respectively, by $0.44,0.19$ and 0.06 relative to the other $\operatorname{Ln}\left(\mathrm{CO}_{3}\right)_{2}{ }^{-}$ (aq). The resultant fittings of $\log \mathrm{B}^{\prime}{ }_{1}\left(\mathrm{LnCO}_{3}{ }^{+}\right)$and $\log B_{2}^{\prime}\left(\operatorname{Ln}\left(\mathrm{CO}_{3}\right)_{2}{ }^{-}\right)$to Eq. (10) are satisfactory as shown in Fig. 3. The $\log \left[\mathrm{B}_{2}^{\prime}\left(\mathrm{Ln}\left(\mathrm{CO}_{3}\right)_{2}^{-}\right) /\right.$ $\left.\mathrm{B}^{\prime}{ }_{1}\left(\mathrm{LnCO}_{3}{ }^{+}\right)\right]$values have also calculcated and compared with $\log \left[\mathrm{B}_{2}\left(\mathrm{Ln}\left(\mathrm{CO}_{3}\right)_{2}{ }^{-}\right) / \mathrm{B}_{1}\left(\mathrm{LnCO}_{3}{ }^{+}\right)\right]$in Fig. 3. The calculated values are listed in Table 2. The structural change effect in $\log \beta_{2}\left(\operatorname{Pr}\left(\mathrm{CO}_{3}\right)_{2}{ }^{-}\right)$ has been estimated to be -0.06 here, but this is comparable with a typical uncertainty $( \pm 0.05)$ for

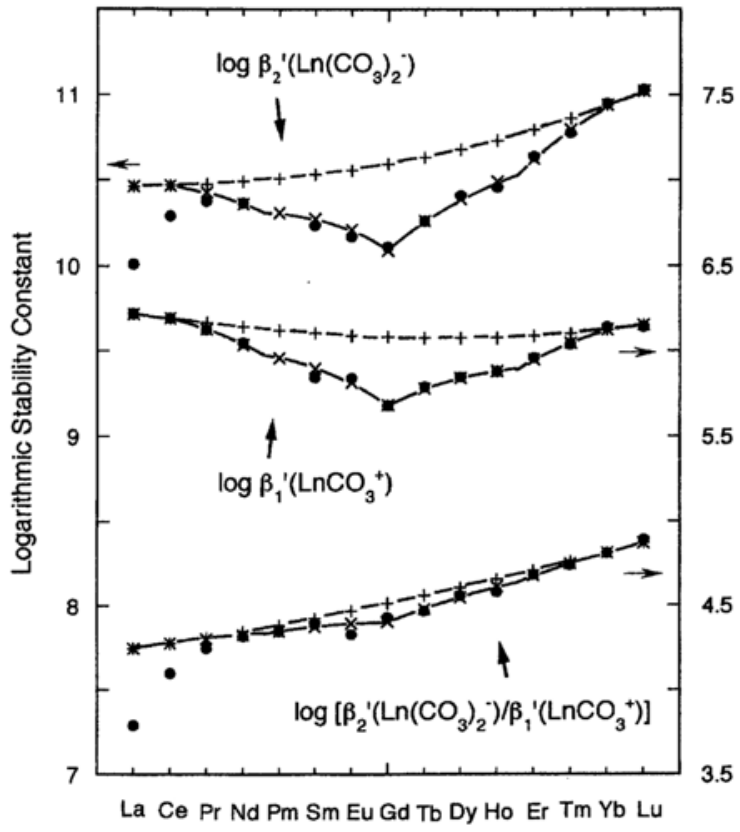

Fig. 3. Least-squares fittings of $\log \beta_{2}^{\prime}\left(\operatorname{Ln}\left(\mathrm{CO}_{3}\right)_{2}^{-}\right)$and $\log \beta_{1}^{\prime}\left(\mathrm{LnCO}_{3}{ }^{+}\right)$to the equation of refined spin-pairing energy theory (Eq. (10)). The primed $\beta$ means that each $\beta$ value is corrected for the structural change in light $\mathrm{Ln}^{3+}(a q)$ and $\mathrm{Ln}\left(\mathrm{CO}_{3}\right)_{2}^{-}(\mathrm{aq})$ series. Filled circles indicate the $\log \beta_{1}$ and $\log \beta_{2}$ values corrected for the hydration change as in Fig. 2. The $\log \left[\beta_{2}\left(\operatorname{Ln}\left(\mathrm{CO}_{3}\right)_{2}^{-}\right) /\right.$ $\left.\beta_{I}\left(\mathrm{LnCO}_{3}{ }^{+}\right)\right]$values are compared with the ratios from the calculated $\log \beta_{1}^{\prime}\left(\mathrm{LnCO}_{3}{ }^{+}\right)$and $\log \beta_{2}^{\prime}\left(\operatorname{Ln}\left(\mathrm{CO}_{3}\right)_{2}{ }^{-}\right)$ values. The multiplication symbols are their fittings to Eq. (10). The plus symbols are for the smooth variations determined as $A+(a+b q) q Z *$. The differences between the two sets of values by multiplication and plus symbols are the intrinsic tetrad effect variations. The structural change in light $\mathrm{Ln}\left(\mathrm{CO}_{3}\right)_{2}^{-}(\mathrm{aq})$ reduces the values of $\log \beta_{2}\left(\operatorname{Ln}\left(\mathrm{CO}_{3}\right)_{2}^{-}\right)$with $\mathrm{Ln}=\mathrm{La}, \mathrm{Ce}$ and $\operatorname{Pr}$ by $0.44,0.19$ and 0.06 relative to the others, respectively (see text).

$\log \beta_{2}\left(\operatorname{Ln}\left(\mathrm{CO}_{3}\right)_{2}^{-}\right)$. Although it is difficult to judge whether the correction value for $\log \beta_{2}$ $\left(\operatorname{Pr}\left(\mathrm{CO}_{3}\right)_{2}^{-}\right)$is the structural change effect or the systemtic bias in the adopted datum, we prefer to the structural change effect at present.

The determined coefficients of $\mathrm{C}_{1}$ and $\mathrm{C}_{3}$ for $\log \beta^{\prime} 1\left(\mathrm{LnCO}_{3}{ }^{+}\right)$are $(0.85 \pm 0.12) \times 10^{-3}$ and $(0.99 \pm 0.40) \times 10^{-4}$, respectively. Those $\mathrm{C}_{1}$ and $\mathrm{C}_{3}$ values for $\log \beta^{\prime}{ }_{2}\left(\operatorname{Ln}\left(\mathrm{CO}_{3}\right)_{2}{ }^{-}\right)$are $(1.09 \pm 0.13)$ 
Table 2. The least-squares fittings of $\log \beta_{1}{ }^{\prime}\left(\mathrm{LnCO}_{3}{ }^{+}\right)$ and $\log \beta_{2}^{\prime}\left(\operatorname{Ln}\left(\mathrm{CO}_{3}\right)_{2}\right)$ to the equation of the refined spinpairing energy theory (RSPET)*

\begin{tabular}{lccc}
\hline & $\begin{array}{c}\log \beta_{1}{ }^{\prime}\left(\mathrm{LnCO}_{3}{ }^{+}\right) \\
\text {(calc.) }\end{array}$ & $\begin{array}{c}\log \beta_{2}{ }^{\prime}\left(\mathrm{Ln}\left(\mathrm{CO}_{3}\right)_{2}{ }^{-}\right) \\
(\text {calc. })\end{array}$ & $\begin{array}{c}\log \left(\mathrm{B}_{2}{ }^{\prime} / \mathrm{B}_{1}{ }^{\prime}\right) \\
\text { (calc.) }\end{array}$ \\
\hline $\mathrm{La}$ & 6.22 & 10.46 & 4.25 \\
$\mathrm{Ce}$ & 6.19 & 10.47 & 4.28 \\
$\mathrm{Pr}$ & 6.13 & 10.43 & 4.30 \\
$\mathrm{Nd}$ & 6.04 & 10.36 & 4.33 \\
$\mathrm{Pm}$ & 5.96 & 10.31 & 4.35 \\
$\mathrm{Sm}$ & 5.90 & 10.28 & 4.38 \\
$\mathrm{Eu}$ & 5.82 & 10.21 & 4.40 \\
$\mathrm{Gd}$ & 5.68 & 10.09 & 4.41 \\
$\mathrm{~Tb}$ & 5.78 & 10.26 & 4.48 \\
$\mathrm{Dy}$ & 5.84 & 10.39 & 4.55 \\
$\mathrm{Ho}$ & 5.88 & 10.49 & 4.61 \\
$\mathrm{Er}$ & 5.95 & 10.63 & 4.68 \\
$\mathrm{Tm}$ & 6.05 & 10.80 & 4.75 \\
$\mathrm{Yb}$ & 6.13 & 10.94 & 4.81 \\
$\mathrm{Lu}$ & 6.15 & 11.02 & 4.87 \\
\hline
\end{tabular}

${ }^{*}$ The data of $\log \beta_{1}\left(\mathrm{LnCO}_{3}{ }^{+}\right)$and $\log \beta_{2}\left(\mathrm{Ln}\left(\mathrm{CO}_{3}\right)_{2}^{-}\right)$in Table 1 , after corrections for the hydration change in the light $\mathrm{Ln}^{3+}(a q)$ series by using $\Delta G_{h}{ }^{*}\left(\mathrm{Ln}^{3+}, a q\right)$ in Kawabe (1999) and for the structural change in $\mathrm{Ln}\left(\mathrm{CO}_{3}\right)_{2}{ }^{-}(\mathrm{aq})$ with $\mathrm{Ln}=\mathrm{La}$, $\mathrm{Ce}$ and $\mathrm{Pr}$, have been fitted to Eq. (10). The corrections to $\log \beta_{2}\left(\mathrm{Ln}\left(\mathrm{CO}_{3}\right)_{2}^{-}\right)$with $\mathrm{Ln}=\mathrm{La}, \mathrm{Ce}$ and $\mathrm{Pr}$ in Table 1 are $+0.44,+0.19$ and +0.06 , respectively. The results here are graphically shown in Fig. 3.

$\times 10^{-3}$ and $(1.14 \pm 0.42) \times 10^{-4}$, respectively. The positive $\mathrm{C}_{1}$ and $\mathrm{C}_{3}$ values suggest that $\mathrm{Ln}^{3+}(\mathrm{aq}$, octahydrate) have larger Racah $\mathrm{E}^{1}$ and $\mathrm{E}^{3}$ parameters than $\mathrm{LnCO}_{3}{ }^{+}(\mathrm{aq})$ and $\mathrm{Ln}\left(\mathrm{CO}_{3}\right)_{2}^{-}(\mathrm{aq})$, although the relative differences in Racah $\mathrm{E}^{1}$ and $\mathrm{E}^{3}$ parameters are only $1 \%$ or less (Kawabe, 1999). The $\mathrm{C}_{1}$ and $\mathrm{C}_{3}$ values of $\log \beta^{\prime}{ }_{1}\left(\mathrm{LnCO}_{3}{ }^{+}\right)$are $25 \%$ and $13 \%$ smaller than those for $\log \beta_{2}^{\prime}$. $\left(\mathrm{Ln}\left(\mathrm{CO}_{3}\right)_{2}^{-}\right)$, respectively. Namely, the $\mathrm{C}_{1}$ and $\mathrm{C}_{3}$ values for the calculated $\log \left[\mathrm{B}_{2}^{\prime}\left(\mathrm{Ln}\left(\mathrm{CO}_{3}\right)_{2}{ }^{-}\right) /\right.$ $\left.B^{\prime}{ }_{1}\left(\mathrm{LnCO}_{3}{ }^{+}\right)\right]$are $(0.24 \pm 0.18) \times 10^{-3}$ and $(0.15 \pm$ $0.58) \times 10^{-4}$, respectively. Although the $\mathrm{C}_{3}$ value involves a relatively large uncetainty, $\mathrm{LnCO}_{3}{ }^{+}(\mathrm{aq})$ have slightly larger Racah $\mathrm{E}^{1}$ and $\mathrm{E}^{3}$ parameters than $\mathrm{Ln}\left(\mathrm{CO}_{3}\right)_{2}{ }^{-}(\mathrm{aq})$. This is the reason that a faintly concave octad variation is seen in $\log \left[\mathrm{B}_{2}\left(\operatorname{Ln}\left(\mathrm{CO}_{3}\right)_{2}{ }^{-}\right) / \mathrm{B}_{1}\left(\mathrm{LnCO}_{3}{ }^{+}\right)\right]$.

Kawabe (1999) did not report $\Delta \mathrm{G}_{\mathrm{h}} *$ for $\mathrm{Pm}^{3+}(\mathrm{aq})$ because of absent thermochemical data of $\Delta \mathrm{G}_{\mathrm{s}}{ }^{\circ}$ for $\mathrm{PmES}_{3} \cdot 9 \mathrm{H}_{2} \mathrm{O}$ and $\mathrm{PmCl}_{3} \cdot 6 \mathrm{H}_{2} \mathrm{O}$. As listed in Table $1, \log \beta_{2}\left(\mathrm{Pm}\left(\mathrm{CO}_{3}\right)_{2}^{-}\right)$and $\log \beta_{1}\left(\mathrm{PmCO}_{3}{ }^{+}\right)$have been estimated by Lee and Byrne (1993). If they are combined with $\log \beta_{2}^{\prime}\left(\mathrm{Pm}\left(\mathrm{CO}_{3}\right)_{2}{ }^{-}\right)$and $\log \mathrm{B}^{\prime}{ }_{1}\left(\mathrm{PmCO}_{3}{ }^{+}\right)$values by the fittings of Fig. 3, we can estimate $\Delta \mathrm{G}_{\mathrm{h}}{ }^{*}$ / (2.303RT) for $\mathrm{Pm}^{3+}(\mathrm{aq})$. The two sets of data give the same $\Delta G_{h}{ }^{*}\left(\mathrm{Pm}^{3+}, \mathrm{aq}\right) /(2.303 R T)$ value of -0.33 , i.e., $\Delta \mathrm{G}_{\mathrm{h}} *\left(\mathrm{Pm}^{3+}, \mathrm{aq}\right)=-1.88 \mathrm{~kJ} / \mathrm{mol}$. If we assume that the uncertainties for $\log \beta_{2}$ $\left(\mathrm{Pm}\left(\mathrm{CO}_{3}\right)_{2}{ }^{-}\right)$and $\log \beta_{1}\left(\mathrm{PmCO}_{3}{ }^{+}\right)$are comparable with those for experimentally determined values $(\approx 0.05)$, then we estimate that $\Delta \mathrm{G}_{\mathrm{h}} *\left(\mathrm{Pm}^{3+}, \mathrm{aq}\right) /$ $(2.303 R T)=-(0.33 \pm 0.05)$, namely $\Delta \mathrm{G}_{\mathrm{h}} *\left(\mathrm{Pm}^{3+}\right.$, aq) $=-(1.9 \pm 0.3) \mathrm{kJ} / \mathrm{mol}$.

Chemical principles underlying "irregular" series variations of Ln(III)-carbonate complexation constants

We can draw several conclusions from the results of Figs. 2 and 3, which are intimately related with important principles of REE chemistry and geochemistry. The first, the hydration change in light $\mathrm{Ln}^{3+}(\mathrm{aq})$ is appreciably distorting the convex tetrad effects in the series variation of $\log \beta_{1}\left(\mathrm{LnCO}_{3}{ }^{+}\right)$and $\log \beta_{2}\left(\operatorname{Ln}\left(\mathrm{CO}_{3}\right)_{2}{ }^{-}\right)$. The distortion can be eliminated by using the estimates for the hydration change effect of $\Delta \mathrm{G}_{\mathrm{h}}$ * (Kawabe, 1999) and $\Delta \mathrm{G}_{\mathrm{h}} *\left(\mathrm{Pm}^{3+}, \mathrm{aq}\right)=-(1.9 \pm 0.3) \mathrm{kJ} / \mathrm{mol}$ in this study. This situation is the same as in the cases of the other aqueous $\mathrm{Ln}$ (III) complexes.

The second, Racah $\mathrm{E}^{1}$ and $\mathrm{E}^{3}$ parameters are deduced to decrease among the three $\mathrm{Ln}$ (III) complex series in the order,

$$
\begin{aligned}
& \mathrm{Ln}^{3+}(\mathrm{aq})(\text { octahydrate }) \\
& \quad>\mathrm{LnCO}_{3}^{+}(\mathrm{aq})>\mathrm{Ln}\left(\mathrm{CO}_{3}\right)_{2}^{-}(\mathrm{aq}) .
\end{aligned}
$$

The order of (11) coincides with the sequence that the water molecules in the first coordination sphere of $\mathrm{Ln}^{3+}(\mathrm{aq})$ are successively replaced by $\mathrm{CO}_{3}{ }^{2-}$. This is a line of evidence for the nephelauxetic effect as to the bondings of $\mathrm{Ln}^{3+}$ with $\mathrm{CO}_{3}{ }^{2-}$ and $\mathrm{H}_{2} \mathrm{O}$. The spectroscopic analyses of various $\mathrm{Ln}$ (III) complexes show that Racah $\mathrm{E}^{1}$ and $\mathrm{E}^{3}$ parameters for $\mathrm{Ln}^{3+}$ ions decrease from the free gaseous ion values as a function of the ani- 
onic ligands in different $\mathrm{Ln}$ (III) complexes, although the decreases are in percent order or less. This is known as the nephelauxetic series of (4f $)^{\mathrm{q}}$ metal ion complexes (Jørgensen, 1971, 1979; Caro et al., 1981). An analogous nephelauxetic series is also known in various $(3 \mathrm{~d})^{\mathrm{q}}$ metal ion complexes (Jørgensen, 1971; Shriver et al., 1994). In the nephelauxetic series, $\mathrm{H}_{2} \mathrm{O}$ is the ligand giving relatively larger Racah parameters than the other anionic ligands with a few exceptions including $\mathrm{F}^{-}$. The result of (11) derived from the RSPET analysis of the stability constants is consistent with the specroscopically known series of nephelauxetic effect.

The third, no structural change is suggested in the $\mathrm{LnCO}_{3}{ }^{+}(\mathrm{aq})$ series as far as the results of Figs. 2 and 3 are concerned. The series variation of $\log \beta_{2}\left(\operatorname{Ln}\left(\mathrm{CO}_{3}\right)_{2}^{-}\right)$exhibits a break at Pr, suggesting that the $\mathrm{Ln}\left(\mathrm{CO}_{3}\right)_{2}^{-}$(aq) series is not a fully isomorphous one. The coordination states of $\mathrm{La}^{3+}$, $\mathrm{Ce}^{3+}$ and probably $\mathrm{Pr}^{3+}$ in $\mathrm{Ln}\left(\mathrm{CO}_{3}\right)_{2}^{-}(\mathrm{aq})$ series may be different from those in the other series members. This structural change is making $\log \beta_{2}\left(\mathrm{La}\left(\mathrm{CO}_{3}\right)_{2}^{-}\right), \quad \log \beta_{2}\left(\mathrm{Ce}\left(\mathrm{CO}_{3}\right)_{2}^{-}\right) \quad$ and $\log \beta_{2}\left(\operatorname{Pr}\left(\mathrm{CO}_{3}\right)_{2}^{-}\right)$smaller, respectively, by 0.44 , 0.19 and 0.06 relative to the other $\operatorname{Ln}\left(\mathrm{CO}_{3}\right)_{2}{ }^{-}(\mathrm{aq})$.

There have been reported the experimental and theoretical studies showing the geochemical significance of lanthanide tetrad effects (Masuda and Ikeuchi, 1979; Masuda et al., 1987; Akagi et al., 1993; Bau, 1996; Kawabe, 1992, 1996; Kawabe et al., 1998). Many geochemists, however, are still skeptical of it (Byrne and Sholkovitz, 1996). For example, in the review as to REE(III) inorganic complexes in aqueous solutions of geochemical interest by Wood (1990), it is written that "the tetrad effect is difficult to detect for most geologically important ligands at $25^{\circ} \mathrm{C}$ and probably is of little consequence to the behavior of REE in low-temperature geological fluids". But, the present study demonstrates that the stability constants for $\mathrm{LnCO}_{3}{ }^{+}(\mathrm{aq})$ and $\mathrm{Ln}\left(\mathrm{CO}_{3}\right)_{2}^{-}(\mathrm{aq})$ indeed involve definite lanthanide tetrad effects. The carbonate ion is the most important anionic ligand for $\mathrm{Ln}^{3+}$ ions in seawater. Wood's (1990) view therefore is now incorrect and unacceptable. The series variations of stability constants for Ln(III)carbonate complexation are explained quantitatively by (i) the lanthanide tetrad effects, (ii) the hydration change in light $\mathrm{Ln}^{3+}(\mathrm{aq})$ series, and (iii) the structural change in the light $\mathrm{Ln}\left(\mathrm{CO}_{3}\right)_{2}{ }^{-}(\mathrm{aq})$ series. All of the three are highly relevant to the important principles of REE chemistry and geochemistry.

Acknowledgments-The author is grateful to A. Ohta and N. Miura for their discussion of Ln(III)-carbonate complexation. He also thanks anonymous reviewers for their criticism. This work was supported partly by the grants Nos. 03402018 and 06453007 from the Ministry of Education, Science and Culture, Japan.

\section{REFERENCES}

Akagi, T., Shabani, A. B. and Masuda, A. (1993) Lanthanide tetrad effect in kimuraiite $\left[\mathrm{CaY}_{2}\left(\mathrm{CO}_{3}\right)_{4} \cdot 6 \mathrm{H}_{2} \mathrm{O}\right]$ : Implication for a new geochemical index. Geochim. Cosmochim. Acta 57, 2899-2905.

Albertsson, J. and Elding, I. (1977) The geometry of the nonaaqualanthanoid(3+) complex in the solid bromates and ethyl sulphates. Acta Cryst. B33, 14601469.

Bau, M. (1996) Controls on the fractionation of isovalent trace elements in magmatic and aqueous systems: evidence from $\mathrm{Y} / \mathrm{Ho}, \mathrm{Zr}, \mathrm{Hf}$, and lanthanide tetrad effect. Contrib. Mineral. Petrol. 123, 323-333.

Byrne, R. H. and Sholkovitz, E. R. (1996) Marine chemistry and geochemistry of the lanthanides. Handbook on the Physics and Chemistry of Rare Earths (Gschneider, K. A. and Eyring, L., eds.), 23, 497593, Elsevier, Amsterdam.

Byrne, R. H., Kump, L. R. and Cantrell, K. J. (1988) The influence of temperature and $\mathrm{pH}$ on trace metal speciation in seawater. Marine Chem. 25, 163-181.

Cantrell, K. J. and Byrne, R. H. (1987) Rare earth element complexation by carbonate and oxalate ions. Geochim. Cosmochim. Acta 51, 597-605.

Caro, P., Deroouet, J., Beaury, L., Teste de Sagey, G., Chaminade, J. P., Aride, J. and Pouchard, M. J. (1981) Interpretation of the optical absorption spectrum and paramagnetic susceptibility of neodimium trifluoride. J. Chem. Phys. 74, 2698-2704.

Gerkin, R. and Reppart, W. (1984) The structures of the lanthanide ethyl sulfate enneahydrates, $\mathrm{M}\left(\mathrm{C}_{2} \mathrm{H}_{5} \mathrm{SO}_{4}\right)_{3} \cdot 9 \mathrm{H}_{2} \mathrm{O}[\mathrm{M}=\mathrm{La}-\mathrm{Lu}$ (except Pm)], at 171 K. Acta Cryst. C40, 781-786. 
Habenschuss, A and Spedding, F. H. (1980) The coordination (hydration) of rare earth ions in aqueous chloride solutions from X-ray diffraction. III. $\mathrm{SmCl}_{3}$, $\mathrm{EuCl}_{3}$, and series behavior. J. Chem. Phys. 73, 442450.

Jørgensen, C. K. (1971) Modern Asppects of Ligand Field Theory. North-Holland, Amsterdam, 538 pp.

Jørgensen, C. K. (1979) Theoretical chemistry of rare earths. Handbook on the Physics and Chemistry of Rare Earths (Gschneider, K. A., Jr. and Eyring, L., eds.), 3, 111-169, North-Holland, Amsterdam.

Kawabe, I. (1992) Lanthanide tetrad effect in the $\mathrm{Ln}^{3+}$ ionic radii and refined spin-pairing energy theory. Geochem. J. 26, 309-335.

Kawabe, I. (1996) Convex tetrad effect variations in REE abundances of "North American shale composite" and "Post-Archean Austraian average shale". Geochem. J. 30, 149-153.

Kawabe, I. (1999) Thermochemical parameters for solution of lanthanide(III) ethylsulphate and trichloride hydrate series: Tetrad effects and hydration change in aqua $\mathrm{Ln}^{3+}$ ion series. Geochem. J. 33, this issue, 249-265.

Kawabe, I., Toriumi, T., Ohta, A. and Miura, N. (1998) Monoisotopic REE abundances in seawater and the origin of seawater tetrad effect. Geochem. J. 32, 213229.

Lee, J. H. and Byrne, R. H. (1992) Examination of comparative rare earth element complexation behavior using linear free-energy relationships. Geochim. Cosmochim. Acta 56, 1127-1137.

Lee, J. H. and Byrne, R. H. (1993) Complexation of trivalent rare earth elements (Ce, $\mathrm{Eu}, \mathrm{Gd}, \mathrm{Tb}, \mathrm{Yb})$ by carbonate ions. Geochim. Cosmochim. Acta 57, 295302.

Liu, X. and Byrne, R. H. (1995) Comparative carbonate complexation of yttrium and gadolinium at $25^{\circ} \mathrm{C}$ and $0.7 \mathrm{~mol} \mathrm{dm}^{-3}$ ionic strength. Marine Chem. 51, 213-221.

Liu, X. and Byrne, R. H. (1998) Comprehensive investigation of yttrium and rare earth element complexation by carbonate ions using ICP-mass spectrometry. J. Solution Chem. 27, 803-815.

Lundqvist, R. (1982) Hydrophilic complexes of the actinides. I. Carbonates of trivalent americium and europium. Acta Chim. Scand. A36, 741-750.

Masuda, A. and Ikeuchi, Y. (1979) Lanthanide tetrad effect observed in marine environment. Geochem. J. 13, 19-22.

Masuda, A., Kawakami, O., Dohmoto, Y. and Takenaka, T. (1987) Lanthanide tetrad effect in nature: two mutually opposite teypes, W and M. Geochem. J. 21, 119-124.

Mioduski, T. and Siekierski, S. (1976) Hydration changes in the lanthanide series as reflected in the solubility of the ethylsulphates. J. inorg. nucl. Chem. 38, 1989-1992.

Ohtaki, H. and Radnai, T. (1993) Structure and dynamics of hydrated ions. Chem. Rev. 93, 1157-1204.

Peppard, D. F., Mason, G. W. and Lewey, S. (1969) A tetrad effect in the liquid-liquid extraction ordering of lanthanides(III). J. inorg. nucl. Chem. 31, 22712272.

Rizkalla, E. N. and Choppin, G. R. (1991) Hydration and hydrolysis of lanthanides. Handbook on the Physics and Chemistry of Rare Earths (Gschneidner, $\mathrm{K}$. A., Jr. and Eyring, L., eds.), 15, 393-442, Elsevier Science Publ. B.V.

Shriver, D. F., Atkins, P. W. and Langford, C. H. (1994) Inorganic Chemistry (2nd ed.). Oxford Univ. Press, Oxford, 819 pp.

Spedding, F. K., Rard, J. A. and Habenschuss, A. (1977) Standard state entropies of the aqueous rare earth ions. J. Phys. Chem. 81, 1069-1074.

Staveley, L. A., Markham, D. R. and Jones, M. R. (1968) The thermochemistry of lanthanide complexes. J. inorg. nucl. Chem. 30, 231-240.

Turner, D. R., Whitfield, M. and Dickson, A. G. (1981) The equilibrium speciation of dissolved components in freshwater and seawater at $25^{\circ} \mathrm{C}$ and 1 atm pressure. Geochim. Cosmochim. Acta 45, 885-881.

Wood, S. A. (1990) The aqueous geochemistry of the rare-earth elements and yttrium. 1 . Review of available low T data for inorganic REE speciation of natural water. Chem. Geol. 82, 159-186.

\section{POSTSCRIPT}

After having returned the revised manuscript of this paper, the present author found that Liu and Byrne (1998) have reported REE(III)-carbonate complexation constants for $\mathrm{Y}$ and all REE except $\mathrm{Pm}$ at $25^{\circ} \mathrm{C}$ and $\mathrm{I}=0.7\left(\mathrm{NaClO}_{4}\right)$ by solvent extraction and ICP-mass spectrometry. They concluded that the new values of $\log \beta_{1}\left(\mathrm{LnCO}_{3}{ }^{+}\right)$and $\log \beta_{2}\left(\mathrm{Ln}\left(\mathrm{CO}_{3}\right)_{2}{ }^{-}\right)$are in good general agreement with the results obtained by using radioisotopes and the estimates by the linear free energy relations (Lee and Byrne, 1993; Liu and Byrne, 1995), which are quoted in Table 1 . Hence the discussion and conclusions here are basically unchanged even if the new data set is adopted. Detailed discussion on the new data will be presented elsewhere. 